\title{
Proinsulin C peptide obviates sympathetically mediated suppression of splenic lymphocyte activity in rats
}

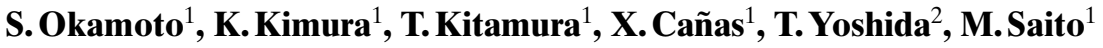 \\ ${ }^{1}$ Department of Biomedical Sciences, Graduate School of Veterinary Medicine, Hokkaido University, Japan \\ ${ }^{2}$ First Department of Internal Medicine, Kyoto Prefectual University of Medicine, Japan
}

\section{Abstract}

Aims/hypothesis. To investigate whether proinsulin C peptide influences sympathetic nerve activity directly or indirectly through parasympathetic nerve activity. Methods. The proliferative response of splenic lymphocytes to Concanavalin A (ConA response) which is known to be suppressed by subjection of rats to footshock or intracerebroventricular injection of corticotropin-releasing factor through sympathetic nerve activation was measured. Effect of $\mathrm{C}$ peptide alone or before subjection to footshock or injection of corticotropin-releasing factor was examined.

Results. Intraperitoneal injection of $\mathrm{C}$ peptide was without effect on the basal ConA response, while subjection to footshock or injection of corticotropinreleasing factor lowered it. In contrast, prior injection of $\mathrm{C}$ peptide obviated the footshock and corticotro- pin-releasing factor-induced suppression of the response. When given intracerebroventricularly, $\mathrm{C}$ peptide was also effective at much smaller doses. Prior injection of atropine cancelled the C-peptide effects.

Conclusion/interpretation. Our results indicate that C peptide counteracts the sympathetic nerve-mediated suppression of splenic lymphocyte proliferation in an atropine-sensitive manner. Thus, $\mathrm{C}$ peptide probably activates the parasympathetic nervous system through the afferent mechanism, that in turn antagonizes the sympathetic nerve-mediated suppression of splenic lymphocyte functions. [Diabetologia (2000) 43: 1512-1517]

Keywords Atropine, C peptide, CRF, footshock, parasympathetic nerve, sympathetic nerve.
A connecting segment of proinsulin, $\mathrm{C}$ peptide, is released from the pancreatic beta cell into the circulation in equimolar amounts to insulin. Recent studies have suggested that $\mathrm{C}$ peptide has several biological activities and that $\mathrm{C}$ peptide concentrations in blood are inversely related to the develop-

Received: 5 June 2000 and in revised form: 31 July 2000

Corresponding author: K. Kimura, $\mathrm{PhD}$, Laboratory of Biochemistry, Department of Biomedical Sciences, Graduate School of Veterinary Medicine, Hokkaido University, Sapporo 060-0818, Japan

Abbreviations: ConA, Concanavalin A; CRF, corticotropin-releasing factor; FS, footshock; i.c.v., intracerebroventricular; $\mathrm{VMH}$, the ventromedial nucleus of the hypothalamus. ment of diabetic complications including microvascular disturbances and neuropathy $[1,2]$. Sympathetic impairment of skin microvascular control seems to be a common finding in patients with Type I (insulin-dependent) diabetes mellitus [3]. Treatment with human $\mathrm{C}$ peptide ameliorates lowered capillary blood cell velocity in Type I diabetic patients compared with healthy subjects [4]. Cardiac autonomic neuropathy occurs early and is frequently found in diabetic patients [5-7]. Short-term infusion of $\mathrm{C}$ peptide in physiological amounts improves the autonomic nerve functions, mainly parasympathetic components, in patients with polyneuropathy and Type I diabetes [8]. These findings suggest that $\mathrm{C}$ peptide influences vascular and neural functions, at least in part, by affecting the autonomic nerve system. The mechanism by which $\mathrm{C}$ pep- 
tide modulates the autonomic nerve function is, however, obscure.

Autonomic nerve activities are varied depending on nutritional and metabolic states and also on some stressors. In various rodent models of obesity such as ventromedial hypothalamus (VMH)-lesioned rats, an increase in parasympathetic and a decrease in sympathetic nerve activities have been documented [9-11]. In contrast, electrical stimulation of the $\mathrm{VMH}$, but not of any other hypothalamic regions such as the paraventricular nucleus (PVN) or the lateral hypothalamic (LH) area, accelerates peripheral norepinephrine turnover, a biochemical index of sympathetic nerve activity [12]. Thus, we propose that the $\mathrm{VMH}$ is a central locus intimately associated with the sympathetic facilitation in peripheral organs, in addition to its widely recognized regulation of feeding behaviours. We also show that the proliferation of splenic lymphocytes in response to a T-cell mitogen, Concanavalin A (ConA), is inhibited by electrical stimulation of the VMH through sympathetic activation [13]. Such a pivotal role of the sympathetic nervous system has also been proposed in the immunosuppression seen under other experimental conditions, such as short-term application of intermittent footshock stress, intracerebroventricular (i.c.v.) injection of corticotropin-releasing factor (CRF) or some cytokines [14-18]. Thus, the mitogenic response of splenic lymphocyte can be used as an indicator of sympathetic nerve activity in vivo.

The aim of our study was to clarify the role of $\mathrm{C}$ peptide in the regulation of sympathetic nerve activity. We, therefore, examined the effect of $\mathrm{C}$ peptide on the mitogenic response of splenic lymphocytes in rats subjected to footshock stress or intracerebroventricularly injected CRF.

\section{Materials and methods}

Materials. Human C peptide was generously provided by Eli Lilly (Indianapolis, Ind., USA) and dissolved in sterilized phosphate buffered saline (PBS). Atropine sulphate was obtained from Tanabe Pharmaceutical (Osaka, Japan). Corticotropin-releasing factor was purchased from Sigma Chemical (St. Louis, Mo., USA). Other reagents were of analytical grade.

Experimental animals. Female Wister rats weighing 160-200 g were housed at $24^{\circ} \mathrm{C}$ with a $12: 12 \mathrm{~h}$ light: dark cycle (light on 0700-1900 hours) and given free access to laboratory chow and water. The experimental procedure and care of animals were in accordance with the guidelines of the Animal Care and Use Committee of Hokkaido University.

Surgery. Under sodium pentobarbital anaesthesia $(45 \mathrm{mg} / \mathrm{kg}$, i.p.), some rats were stereotaxically implanted with a stainless steel cannula $(0.4 \mathrm{~mm}$ outside diameter $)$ into the left cerebral ventricle $(0.9 \mathrm{~mm}$ posterior to the bregma, $1.7 \mathrm{~mm}$ lateral from the midline, $3.3 \mathrm{~mm}$ below the dura), according to the stereotaxic coordinates adopted from the brain atlas [19]. After a recovery period of 10-14 days, they were used for experiments.
Footshock procedure. A plastic chamber (width $45 \mathrm{~cm} \times$ depth $45 \mathrm{~cm} \times$ height $46 \mathrm{~cm}$ ) was equipped with shock grids at intervals of $10 \mathrm{~mm}$ and separated into nine blocks (width $15 \mathrm{~cm} \times$ depth $15 \mathrm{~cm} \times$ height $46 \mathrm{~cm}$ ). The footshock group was given a single 60-min session during which electrical shocks were applied every $1 \mathrm{~min}$. Each shock consisted of $2 \mathrm{~s}$ of $2 \mathrm{~mA}$ scrambled footshock for the first $30 \mathrm{~min}$ and $2 \mathrm{~s}$ of $3 \mathrm{~mA}$ for the next $30 \mathrm{~min}$. Immediately after the footshock, rats were decapitated and the spleen was removed. This was usually done between 0900 and 1000 hours. Some rats were injected with C peptide ( $1 \mathrm{mg} / \mathrm{kg}$ for i. p. and $2 \mu \mathrm{g} / \mathrm{rat}$ for i.c. v.) or PBS $30 \mathrm{~min}$ before the footshock. Atropine $(1 \mathrm{mg} / \mathrm{kg}$, i. p. $)$ was given 45 min before the footshock.

Intracerebroventricular injection of CRF. Corticotropin-releasing factor (100 ng/rat) was dissolved in $5 \mu \mathrm{l}$ sterilized PBS and injected intracerebroventricularly. At $30 \mathrm{~min}$ after the injection, rats were decapitated and the spleen was removed. Some rats were injected intraperitoneally with $\mathrm{C}$ peptide $(1 \mathrm{mg} / \mathrm{kg})$ 30 min before the CRF-injection.

Assay of mitogenic response of splenic lymphocytes. A splenocyte suspension was prepared by gentle homogenizing of the spleen with a glass homogenizer. Lymphocytes were isolated by $65 \%$ Percoll (Pharmacia, Piscataway, N.J., USA) densitygradient sedimentation [20], washed four times in PBS, and finally suspended at $5 \times 10^{6}$ cells/ml in RPMI-1640 medium (Sigma) supplemented with $5 \%$ heat-inactivated fetal calf serum (Gibco BRL, Grand Island, N. Y., USA). The proliferative response to a mitogen, ConA (Sigma), was measured as reported previously [21]. Briefly, the lymphocyte suspension $\left(5 \times 10^{5}\right.$ cells/well) was incubated in the presence of $0-8 \mu \mathrm{g} / \mathrm{ml}$ ConA at $37^{\circ} \mathrm{C}$ for $68 \mathrm{~h}$ in a humidified incubator with $5 \% \mathrm{CO}_{2}$ and added to 3-[4,5-dimethyl thiazol-2-yl]-2,5-diphenyltetrazolium bromide (Sigma). After another 4-h incubation at $37^{\circ} \mathrm{C}, 0.04$ $\mathrm{N} \mathrm{HCl}$ in isoproterenol was added and the optical density was read at $570 \mathrm{~nm}$.

Statistical analysis. Data were expressed as means \pm SEM and analysed by ANOVA, with post hoc testing using the Newman-Keuls multiple-range test. A $p$ value less than 0.05 was considered to be statistically significant.

\section{Results}

It has been reported that splenic lymphocyte functions are reduced under conditions that activate the sympathetic nerve supply to the spleen [14-18]. To clarify this, first we applied intermittent electrical footshock to rats for $1 \mathrm{~h}$, prepared splenic lymphocytes, and examined their proliferative response to a T-cell mitogen, ConA. The splenic lymphocytes obtained from control rats without footshock showed a concentration-dependent proliferation in response to ConA (Fig.1). The cells obtained from footshocked rats also proliferated in the presence of ConA but their response was much weaker, being about half of that in the controls even at a ConA concentration of $8 \mu \mathrm{g} / \mathrm{ml}$. To measure the effect of $C$ peptide on the proliferation of splenic lymphocytes, $\mathrm{C}$ peptide $(1 \mathrm{mg} / \mathrm{kg})$ was injected intraperitoneally and after $1.5 \mathrm{~h}$ the ConA response was examined. The 

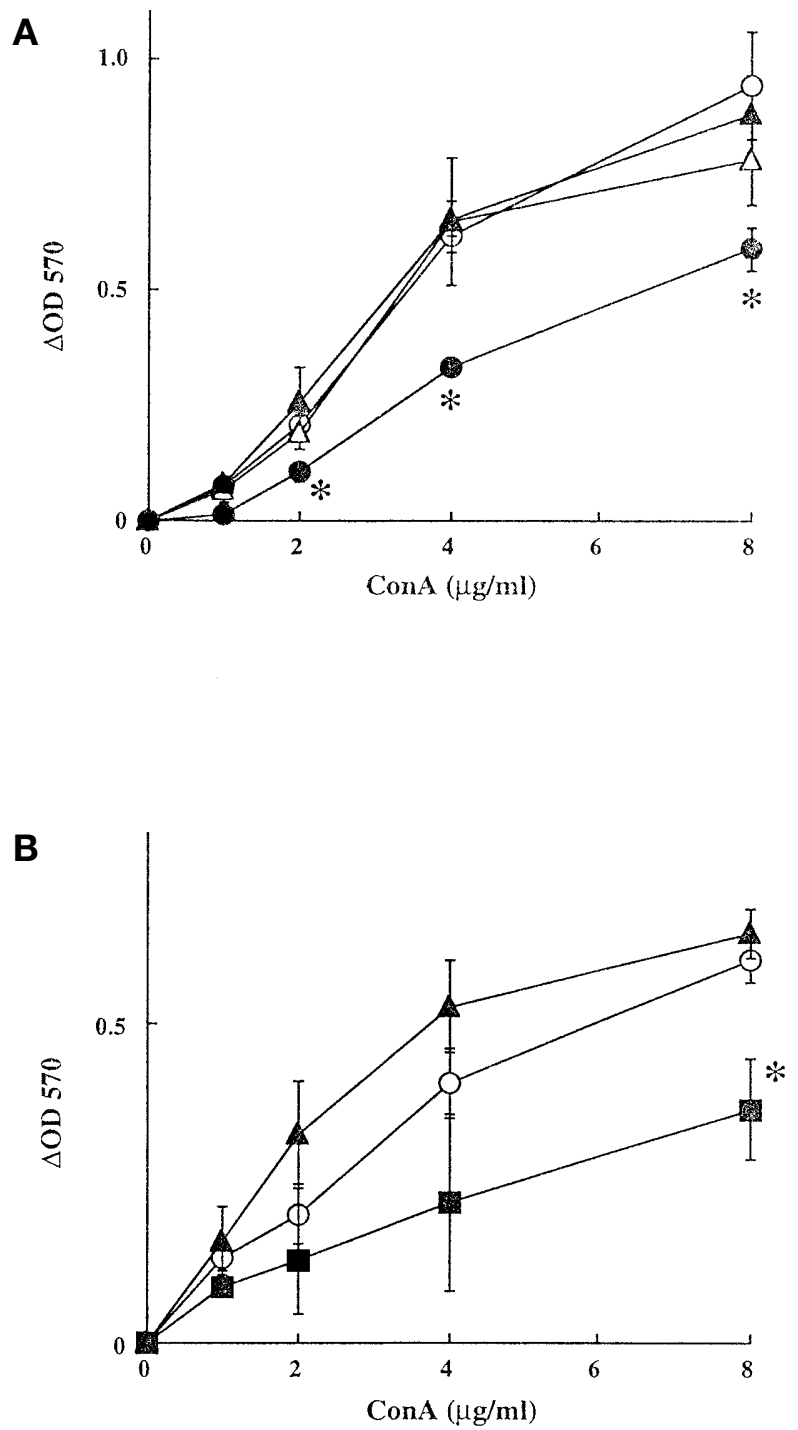

Fig.1A, B. Recovery effect of intraperitoneal injection of $\mathrm{C}$ peptide on the footshock-induced or CRF-induced suppression of proliferative response of splenic lymphocytes. A Rats were given footshock (closed symbols) as described in "Materials and Methods" and the ConA response of splenic lymphocytes was measured in vitro. C peptide $(1 \mathrm{mg} / \mathrm{kg}$, triangle) or PBS (circle) was intraperitoneally injected $30 \mathrm{~min}$ before the footshock. Open symbols, rats without given footshock. B Rats were intracerebroventricularly injected with CRF (100 $\mathrm{ng} / \mathrm{rat}, \boldsymbol{\square})$ or PBS ( $\bigcirc)$, and the ConA response was measured. When given, $C$ peptide $(1 \mathrm{mg} / \mathrm{kg}, \boldsymbol{\Delta})$ was intraperitoneally injected 30 min before the CRF injection. Data in $\mathbf{A}$ and $\mathbf{B}$ are means \pm SEM for four rats. ${ }^{*}, p<0.05$ vs PBS-injected control

cells from rats injected with $\mathrm{C}$ peptide responded to ConA and proliferated to a similar extent to those of control rats injected with PBS. Notably, the cells prepared from the foot-shocked rats that received C peptide also proliferated almost similarly to the rats without footshock. Thus, the ConA response of splenic lymphocyte was suppressed by the footshock, but prior i.p. injection of $\mathrm{C}$ peptide prevented the footshock-induced suppression.

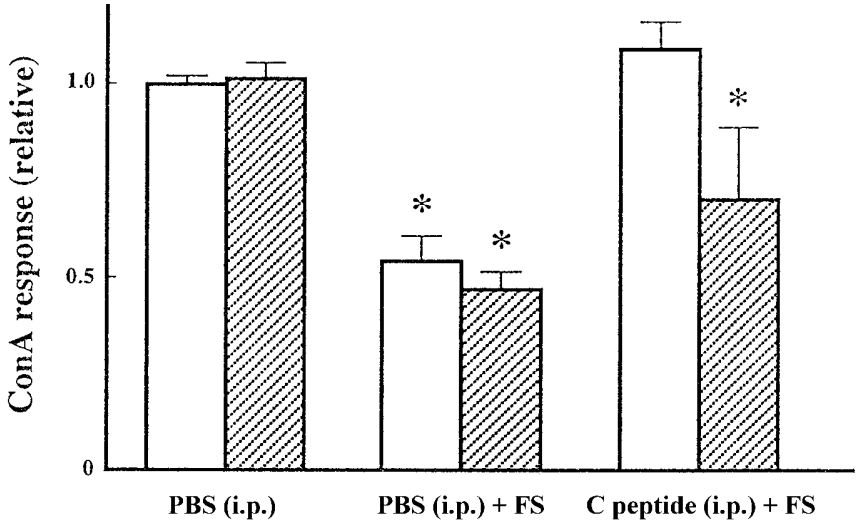

Fig. 2. Effects of atropine on the modulation of splenic lymphocyte proliferation by footshock and $\mathrm{C}$ peptide. The ConA response was measured as in Fig. $1 \mathrm{~A}$ and those at $8 \mu \mathrm{g} / \mathrm{ml}$ ConA were indicated. C peptide $(1 \mathrm{mg} / \mathrm{kg}$, i.p.) and atropine $(1 \mathrm{mg} / \mathrm{kg}$, i.p., $\square)$ was injected 30 and $45 \mathrm{~min}$ before the footshock (FS), respectively. Open column, rat without given atropine. Data are means \pm SEM for four rats. ${ }^{*}, p<0.05$ vs PBSinjected controls

Intracerebroventricular injection of CRF is also known to cause the sympathetically mediated suppression of splenic lymphocyte activity [16-18]. The effect of $\mathrm{C}$ peptide on the CRF-induced suppression of ConA response was examined. When CRF was given to the lateral ventricle, the ConA response was about half of the control (Fig. 1). When C peptide was given before $\mathrm{CRF}$-injection, the ConA response recovered to almost the same as the control. When the direct effect of $\mathrm{C}$ peptide on splenic lymphocyte proliferation was examined, $C$ peptide failed to affect the ConA response (data not shown).

To find a possible role of the parasympathetic nervous system in the effect of $C$ peptide, atropine was injected $15 \mathrm{~min}$ before the $\mathrm{C}$ peptide injection. Atropine showed no noticeable effect on the ConA response in controls or foot-shocked rats but it statistically significantly reduced the response in footshocked and C-peptide-treated rats (Fig. 2). Thus, atropine blocked the effect of $\mathrm{C}$ peptide, suggesting that the effect of $C$ peptide which was observed is mediated by the parasympathetic nervous system.

Finally, the effect of intracranially injected $C$ peptide on the ConA response was examined. When $\mathrm{C}$ peptide was injected intracerebroventricularly at a dose of $2 \mu \mathrm{g}$ that was less than 1/100 of the i.p. injection, the footshock-induced suppression of ConA response was prevented (Fig. 3). Injection of atropine before the i.c. v. injection of $\mathrm{C}$ peptide cancelled the effect of $\mathrm{C}$ peptide. Thus, $\mathrm{C}$ peptide given intracranially, as that given peripherally, prevented the sympathetic nerve-mediated suppression of the ConA response and the effect of $\mathrm{C}$ peptide was sensitive to atropine. 


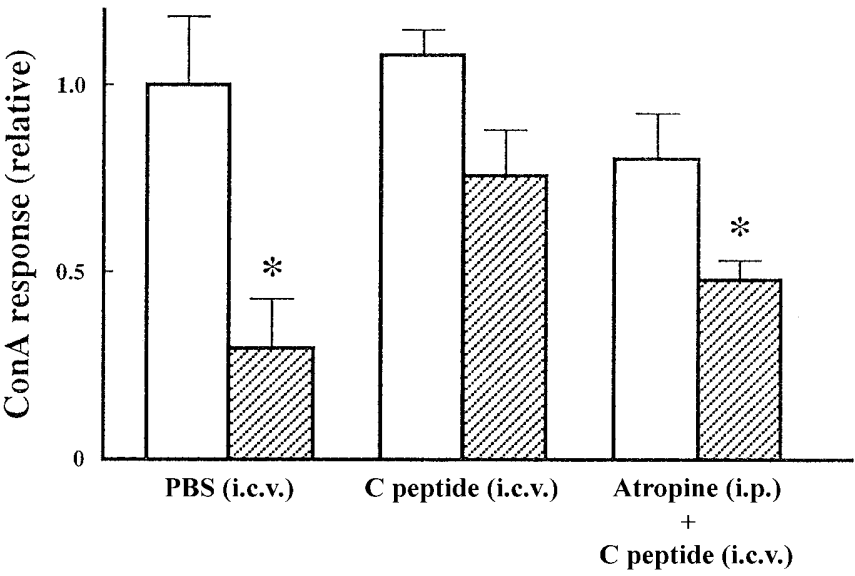

Fig.3. Effect of intracerebroventricular injection of $\mathrm{C}$ peptide on the footshock-induced suppression of splenic lymphocyte proliferation. C peptide $(2 \mu \mathrm{g} / \mathrm{rat})$ or PBS was intracerebroventricularly injected $30 \mathrm{~min}$ before the footshock $(\square)$. $\square$, rats without footshock. Atropine $(1 \mathrm{mg} / \mathrm{kg}$, ip) was given 45 min before the footshock. Data are means \pm SEM for four rats. *, $p<0.05$ vs controls

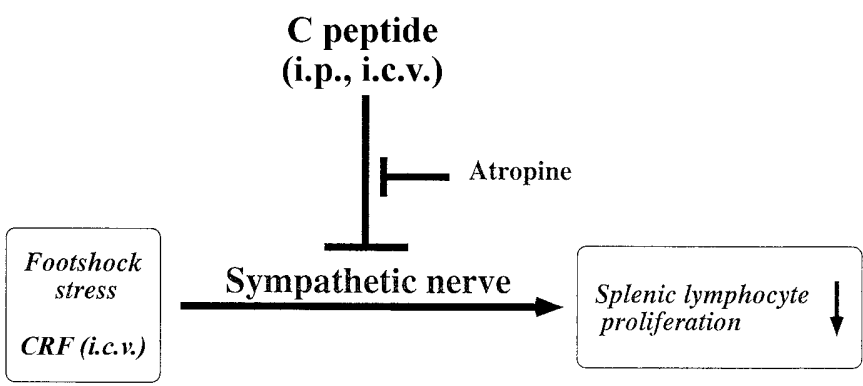

Fig.4. Summary of C peptide's action on the footshock-induced and CRF-induced suppression of splenic lymphocyte proliferation

\section{Discussion}

We examined the effect of $\mathrm{C}$ peptide on the proliferative response of splenic lymphocytes to ConA and found that either i.p. or i.c.v. injection of $\mathrm{C}$ peptide obviates the suppressive effects of footshock and CRF on the ConA response. Moreover, we found that the effect of $\mathrm{C}$ peptide was prevented by atropine, a parasympathicolytic agent. Because the footshock-induced and CRF-induced suppression is known to be mediated through sympathetic activation, our results suggest that $\mathrm{C}$ peptide antagonizes sympathetically mediated suppression of splenic lymphocyte function by parasympathetic nerve activation (Fig. 4).

Reduced vagal tone is often found in Type I diabetic patients and is associated with gastric dysmotility [22], progression of nephropathy [23] and cardiac dysfunction [7]. Although the pathogenesis of diabetic neuropathy is not known, a lack of endogenous C peptide is a possible cause $[1,2]$. Our results suggest that $\mathrm{C}$ peptide is an activator of the parasympathetic nervous system. In support of this idea, infusion of $\mathrm{C}$ peptide in physiological amounts was shown to improve cardiac autonomic nerve functions, mainly parasympathetic components, in Type I diabetic patients [8].

The mitogenic response of splenic lymphocytes is inhibited after application of footshock or i.c. v. injection of CRF. Because the suppressive effect is abolished by surgical denervation of the splenic nerve and $\beta$-adrenergic blockers [14-17], the footshock-induced and CRF-induced suppression is mediated by norepinephrine acting through the $\beta$-adrenergic receptors on the surface of splenic lymphocytes. In contrast, $\beta$ adrenergic blockers have been shown to retard the urinary albumin excretion rate in incipient nephropathy [24] and to reduce mortality after myocardial infraction in diabetic patients [25]. In addition, $\beta$-adrenergic blockers increase vagal cardiac inhibition [26,27]. It is thus suggested that $\beta$-adrenergic blockers not only inhibit the sympathoadrenal system but also cause changes in autonomic tone. Treatment with $\mathrm{C}$ peptide has been shown, however, to decrease glomerular hyperfiltration, improve membrane function in glomeruli cells [28-30], increase blood flow and capillary diffusion capacity in skeletal muscle [31] and improve autonomic function [8] in Type I diabetic patients. Activation of $\mathrm{Na}^{+}, \mathrm{K}^{+}$-ATPase activity by $\mathrm{C}$ peptide in rat renal tubule cells has been suggested to be a mechanism for the renal effect of $C$ peptide [32]. In addition, a similarity in the effects between $\beta$-adrenergic blocker and $C$ peptide, together with the present results, imply that the effects of $\mathrm{C}$ peptide are, at least in part, attributed to alteration of the balance between sympathetic and parasympathetic nervous activities. Such alteration in the balance of autonomic nervous activity might be a mechanism by which $\mathrm{C}$ peptide obviates the sympathetic nerve-mediated suppression of splenic lymphocyte function.

C peptide injected into the cerebroventricule was as effective as that injected intraperitoneally and the effect was similarly blocked by atropine. $\mathrm{C}$ peptide is present in similar amounts to insulin in brain homogenates, suggesting the expression of proinsulin in the brain [33]. Thus, like other neuropeptides, C peptide could exert its function directly in the central nervous system. No report describing the presence of a specific receptor for $\mathrm{C}$ peptide in the brain has, however, been published. This is probably due to failure of iodinated $\mathrm{C}$ peptide to detect any specific binding sites on the membrane of various cells except islet beta cells $[34,35]$ and lack of cDNA cloning for $\mathrm{C}$ peptide receptor. Recently, a new method for detecting specific binding for $\mathrm{C}$ peptide in cell membranes has been developed [35]. Studies using this method will help explain the role of $\mathrm{C}$ peptide in the brain.

We used human $\mathrm{C}$ peptide, which has nine aminoacid substitutions for rat $\mathrm{C}$ peptide in our study. $\mathrm{Hu}$ - 
man $\mathrm{C}$ peptide as well as rat $\mathrm{C}$ peptide have, however, been shown to prevent diabetes-induced and hyperglycaemia-induced vascular and neural dysfunction in the rat in vivo and in vitro $[36,37]$. Thus, some conserved region of these $\mathrm{C}$-peptides is important for their activity.

Our study shows that proinsulin $\mathrm{C}$ peptide counteracts a well-characterized sympathetic nerve-mediated function. Moreover, our results strongly suggest that $\mathrm{C}$ peptide influences the parasympathetic nervous system by direct action on the brain or some peripheral mechanisms.

Acknowledgements. This work was supported in part by PROBRAIN from the Bio-oriented Technology Research Advancement Institution, Japan.

\section{References}

1. Wahren J, Johansson BL (1998) New aspects of C-peptide physiology. Horm Metab Res 30: A2-A5

2. Wahren J, Johansson BL, Wallberg-Henriksson, H (1994) Does C-peptide have a physiological role? Diabetologia 37 [Suppl 2]: S99-S107

3. Bernardi L, Rossi M, Leuzzi S, et al. (1997) Reduction of $0.1 \mathrm{~Hz}$ microcirculatory fluctuations as evidence of sympathetic dysfunction in insulin-dependent diabetes. Cardiovasc Res 34: 185-191

4. Forst T, Kunt T, Pohlmann T et al. (1998) Biological activity of C-peptide on the skin microcirculation in patients with insulin-dependent diabetes mellitus. J Clin Invest 101: 2036-2041

5. Schnell O, Muhr D, Weiss M et al. (1997) Three-year follow-up on scintigraphically assessed cardiac sympathetic denervation in patients with long-term insulin-dependent (type I) diabetes mellitus. J Diabetes Complications 11: 307-313

6. Valensi P, Huard JP, Giroux C, Attali JR (1997) Factors involved in cardiac autonomic neuropathy in diabetic patients. J Diabetes Complications 11: 180-187

7. Willenheimer RB, Erhardt LR, Nilsson H, Lilja B, JuulMoller S, Sundkvist G (1998) Parasympathetic neuropathy associated with left ventricular diastolic dysfunction in patients with insulin-dependent diabetes mellitus. Scand Cardiovasc J 32: 17-22

8. Johansson BL, Borg K, Fernqvist-Forbes E, Odergren T, Remahl S, Wahren J (1996) C-peptide improves autonomic nerve function in IDDM patients. Diabetologia 39: 687-695

9. Jeanrenaud B, Halimi S, Van de Werve G (1985) Neuro-endocrine disorder seen as triggers of the triad: obesity-insulin resistance-abnormal glucose tolerance. Diabetes Metab Rev 1: 261-291

10. Yoshimatsu H, Niijima A, Oomura Y, Yamada K, Katafuchi T (1984) Effects of hypothalamic lesion on pancreatic autonomic nerve activity in the rat. Brain Res 303: $147-152$

11. Niijima A, Jeanrenaud FR, Jeanrenaud B (1984) Role of ventromedial hypothalamus on the sympathetic efferents of brown adipose tissue. Am J Physiol 247: R650-R654

12. Saito M, Minokoshi Y, Shimazu T (1989) Accelrated norepinephrine turnover in peripheral tissue after ventromedial hypothalamic stimulation in rats. Brain Res 481: 298-303
13. Okamoto S, Ibaraki K, Hayashi S, Saito M (1996) Ventromedial hypothalamus suppresses splenic lymphocyte activity through sympathetic innervation. Brain Res 739: 308-313

14. Cunnick JE, Lysle DT, Kucicski BJ, Rabin BS (1990) Evidence that shock-induced immuno suppression is mediated by adrenal hormones and peripheral $\beta$-adrenergic receptors. Pharmacol Biochem Behav 36: 641-651

15. Wan W, Vriend CY, Wetmore L, Gatner JG, Greenberg AH, Nance DM (1993) The effects of stress on splenic immune function are mediated by the splenic nerve. Brain Res Bull 30: 101-105

16. Dunn AJ, Berridge CW (1990) Physiological and behavioral responses to corticotropin-releasing factor administration: is CRF a mediator of anxiety or stress response? Brain Res Brain Res Rev 15: 71-100

17. Okamoto S, Ishikawa I, Kimura K, Saito M (1998) Potent suppressive effects of urocortin on splenic lymphocyte activity in rats. Neuroreport 9: 4035-4039

18. Okamoto S, Irie Y, Ishikawa I, Kimura K, Saito M (2000) Central leptin suppresses splenic lymphocyte functions through activation of the corticotropin-releasing hormonesympathetic nervous system. Brain Res 855: 192-197

19. Pellegrino LJ, Pellegrino AS, Cushman AJ (1979) Stereotaxic Atlas of the rat brain. Plenum Press, New York

20. Keller SE, Schleifer SE, Mckegney FP, Sherman J, Camerino M, Stein M (1982) A simplified method for assessing PHA induced stimulation of rat peripheral blood lymphocytes. J Immunol Methods 51: 287-291

21. Mosmann T (1983) Rapid colorimetric assay for cellular growth and survival: application to proliferation and cytotoxicity assay. J Immunol Methods 65: 55-63

22. Undeland KA, Hausken T, Svebak S, Aanderud S, Berstad A (1996) Wide gastric antrum and low vagal tone in patients with diabetes mellitus type 1 compared to patients with functional dyspesia and healthy individuals. Dig Dis Sci 41: 9-16

23. Molgaard H, Christensen P, Sorensen KE, Christensen CK, Mogensen CE (1992) Association of 24-h cardiac parasympathetic activity and degree of nephropathy in IDDM patients. Diabetes 41: 812-817

24. Rudberg S, Osterby R, Bangstad HJ, Dahlquist G, Persson B (1999) Effect of angiotensin converting enzyme inhibitor or beta blocker on glomerular structural changes in young microalbuminuric patients with Type I (insulin-dependent) diabetes mellitus. Diabetologia 42: 589-595

25. Kjekshus J, Gilpin E, Cali G, Blackey AR, Henning H, Ross J Jr (1990) Diabetic patients and beta-blockers after acute myocardial infarction. Eur Heart J 11: 43-50

26. Haberthur C, Schachinger H, Langewitz W, Ritz R (1999) Effect of beta blockade with and without sympathomimetic activity (ISA) on sympathovagal balance and baroreflex sensitivity. Clin Physiol 19: 143-152

27. Tygesen H, Andersson B, Di Lenarda A et al. (1999) Potential risk of beta-blockade withdrawal in congestive heart failure due to abrupt autonomic changes. Int J Cardiol 68: 171-177

28. Johansson BL, Kernell A, Sjoberg S, Wahren J (1993) Influence of combined C-peptide and insulin administration on renal function and metabolic control in diabetes type 1 . J Clin Endocrinol Metab 77: 976-981

29. Sjoquist M, Huang W, Johansson BL (1998) Effects of Cpeptide on renal function at the early stage of experimental diabetes. Kidney Int 54: 758-764

30. Johansson BL, Sjoberg S, Wahren J (1992) The influence of human C-peptide on renal function and glucose utilization in Type I (insulin-dependent) diabetic patients. Diabetologia 35: 121-128 
31. Johansson BL, Linde B, Wahren J (1992) Effects of C-peptide on blood flow, capillary diffusion capacity and glucose utilization in the exercising forearm of Type I (insulin-dependent) diabetic patients. Diabetologia 35: 1151-1158

32. Ohtomo Y, Aperia A, Sahlgren B, Johansson BL, Wahren J (1996) C-peptide stimulates rat renal tubular $\mathrm{Na}^{+}, \mathrm{K}^{+}$-ATPase activity in synergism with neuropeptide Y. Diabetologia 39: 199-205

33. Frolich L, Blum-Degen D, Bernstein H-G et al. (1998) Brain insulin and insulin receptors in aging and sporadic Alzheimer's disease. J Neural Transm 105: 423-438

34. Flatt PR, Swanston-Flatt SK, Hampton SM, Bailey CJ, Marks V (1986) Specific binding of the C-peptide of proin- sulin to cultured $\beta$-cells from a transplantable rat islet cell tumor. Biosci Rep 6: 193-199

35. Rigler R, Pramanik A, Jonasson P et al. (1999) Specific binding of proinsulin C-peptide to human cell membranes. Proc Natl Acad Sci USA 96: 13318-13323

36. Ido Y, Vindigni A, Chang K et al. (1997) Prevention of vascular and neural dysfunction in diabetic rats by $\mathrm{C}$-peptide. Science 277: 563-566

37. Jensen ME, Messina EJ (1999) C-peptide induces a concentration-dependent dilation of skeletal muscle arterioles only in presence of insulin. Am J Physiol 276: H1223-H1228 